\title{
Light Rail and Land Use Change: Rail Transit's Role in Reshaping and Revitalizing Cities
}

\author{
Christopher D. Higgins, Mark R. Ferguson, Pavlos S. Kanaroglou \\ McMaster University
}

\begin{abstract}
Planners and policymakers often cite the tangible objective of land use change as a primary motivation and justification for an investment in light rail transit (LRT). But how has light rail performed with respect to achieving this goal? This paper reviews and synthesizes the previous literature on LRT and other rail rapid transit systems in North America, demonstrating that rail transit alone is not a primary driver of land use change and that six beneficial factors affect the ability of these systems to have a measurable impact on reshaping and revitalizing cities.
\end{abstract}

\section{Introduction}

The past three decades have seen a remarkable growth in the number of light rail transit (LRT) systems in North America, with more route-kilometers of LRT constructed than any other type of rail transit technology. The development of these new systems provides an interesting opportunity to critically examine the LRT planning process, specifically the narrative crafted by policy and planning actors to motivate and justify investments in LRT. As a city considers such a project, the debate inevitably focuses on the benefits that can be achieved. This often includes tangible objectives such as lower levels of congestion and air pollution and the promotion of transit-oriented land use change, as well as intangible symbolic or emotional benefits, such as remaking the image of the host city as more modern 
and competitive in the global economy. In some cases, the accumulation of these benefits has been true. However, the idea that these benefits are not only transferrable but inevitable in other host cities is at odds with of the North American rail transit experience. Making unsubstantiated claims of the transformative powers of these systems is both irresponsible and hazardous to short- and long-term public and political confidence in rapid transit as a tool for encouraging more sustainable patterns of growth and travel.

The impetus for this research is the $\$ 829$ million $14 \mathrm{~km}$ B-Line LRT in Hamilton, one of several LRT projects underway in the Province of Ontario. Currently in planning, the policy and planning narrative in support of the project is one heavily based in the goals of city building and revitalization (City of Hamilton 2010). These propositions employed by planners and policymakers in support of the B-Line LRT are valuable for helping to shape public and political support for the project and certainly laudable from a planning perspective. But the determination to market light rail as a driver of land use change raises important questions. How has light rail performed in relation to such goals? Can LRT act as a driver of land use change on its own? What factors must be in place to achieve such objectives? And is there an order of importance among these factors?

The present paper reviews and synthesizes the previous literature on rail rapid transit systems in North America with respect to their abilities to achieve land use planning objectives. This question has received considerable attention from a large number of authors, although this has resulted in a set of conclusions that are fragmented among several works. In response, this paper first presents an assessment of six factors that are beneficial for inducing land use change with rapid transit, factor impacts, and interactions and an examination of the land use impacts of recent LRT investments. The paper then discusses confounding influences and challenges associated with attributions of causality, finishing with conclusions that should be considered by planners and policymakers in ex ante and ex post evaluations of the expected benefits of such systems in other cities and regions in North America. But to begin, it is useful to theorize the two broad tangible rationales that inform an investment in rail transit. As Cohen-Blankshtain and Feitelson (2011) explain, the first is to achieve high levels of ridership by responding to existing travel demand, while the second is to create demand by affecting land use settlement patterns and travel behavior. 


\section{Existing Demand: Rapid Transit and Ridership}

It is believed that the accessibility benefit obtained by providing rail transit service to a congested corridor will result in increased transit ridership and a cost-effective transit line, as well as result in a reduction in congestion, travel times, and harmful emissions (Cohen-Blankshtain and Feitelson 2011). However, previous research has been critical of the ridership and cost projections used to rationalize investments in rapid transit in a number of cities, finding them subject to systematic cost overruns and ridership shortfalls (Flyvbjerg et al. 2005; Mackett and Edwards 1998; Pickrell 1992; Siemiatycki 2009; Wachs 1987).

What factors have contributed to this trend in rail transit infrastructure projects? Several explanations have appeared in the literature. Public sector auditors have tended to view the inaccuracy of projections as a result of technical errors in forecasting. Academic research has adopted another perspective, viewing the chronic overestimation of benefits and underestimation of costs as strategic misrepresentation, both conscious and unconscious, by project managers with a vested interest in a project's success (Flyvbjerg et al. 2005; Siemiatycki 2009).

Another explanation can be found in examining the connection between land use and transportation where, at its most basic, the existing built environment provides a foundation for activity patterns and travel demand in the urban system (Figure 1). Early research into the role of land use and travel demand established minimum densities required for cost-effective transit service (Pushkarev and Zupan 1977). In addition to density, later research has found the combined effect of several measures of the built environment to be important in affecting travel behavior, such as the diversity of land use mix, urban design, destination accessibility, and distance to transit (Ewing and Cervero 2010). For light rail specifically, recent work has further explored the link between LRT ridership and factors such as residential and employment densities, transit accessible destinations, and service quality in the United States (Kuby et al. 2004) and Europe, Australia, and North America (Currie et al. 2011). Constructing light rail in corridors where these factors are present is crucial to attracting high levels of initial transit ridership and realizing the congestion and emissions benefits associated with it. 


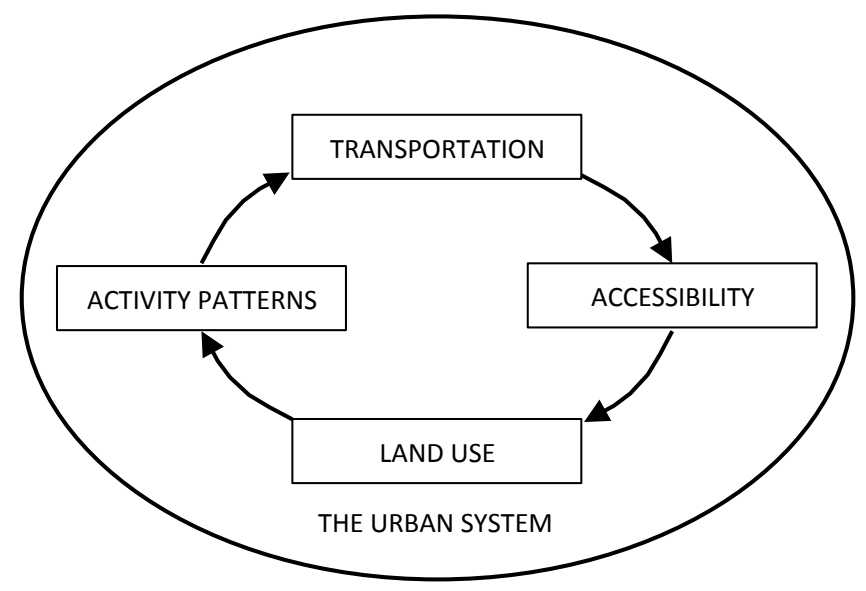

Source: Giuliano (2004)

Figure 1. Transportation-Land Use Connection

\section{Induced Growth and Travel Demand: Land Use Impacts of Rapid Transit}

The second rationale for an investment in light rail transit is to induce land use change in areas with unrealized developmental potential attributed to a lack of accessibility (Cohen-Blankshtain and Feitelson 2011). It is argued that once a light rail line is constructed, the accessibility benefits of the new transit facility will affect land use by increasing land rents and promoting higher density development, which, in turn, can alter travel patterns and mode choices over time within the urban system. Indeed, many proponents of light rail argue that an investment in LRT can spur urban growth, revitalize declining areas, and promote more transitoriented development (TOD) in a city's downtown core, inner suburbs, and outlying areas. But what does the literature say regarding the impact of rapid transit investments on land use change?

Handy (2005) notes that, in theory, rapid transit can potentially have both a "generative" and "redistributive" impact on land use and development. However, a growing body of scholarly research challenges the generative land use effects of rapid transit, arguing that rail transit, at least on its own, is insufficient for generating new urban economic or population growth (Babalik-Sutcliffe 2002; Black 1993; Cervero and Landis 1997; Cervero and Seskin 1995; Hass-Klau and Crampton 2002; Knight and Trygg 1977a, 1977b; Vesalli 1996). Yet, there is evidence that light rail 
and other rapid transit systems can have a substantial redistributive impact and influence where and how growth in a region occurs (Cervero 1984; Cervero and Seskin 1995; Handy 2005; Huang 1996; Knight and Trygg 1977a, 1977b; Vesalli 1996). As such, rapid transit should not be understood as a primary driver of new growth and revitalization, but rather as a tool to guide growth that would have occurred anyhow. But even the redistributive effect of rapid transit is greatly influenced by the presence of a number of basic factors.

\section{Six Primary Factors Affecting Land Use Change}

Knight and Trygg (1977a) were among the first to delineate several factors that affected the decision to develop land around rapid transit stations and their work has provided the foundation for research in this area since. Later studies tended to draw similar conclusions, although few appear to have specifically followed the approach of Knight and Trygg (1977a), instead formulating their own methodologies and settling on variations of which factors were most important. The end result has been a body of empirical research that is fragmented across several studies.

Nevertheless, several common themes are apparent. Our review of the literature has revealed six important factors that contribute to the ability of investments in rapid transit to promote land use change, without which rail transit is not likely to have a measurable impact on development. Each factor is outlined briefly below and their sources are presented in Table 1. From this base, we update and augment the work of Knight and Trygg (1977a) to display graphically the six primary factors and their associated determinants that affect the decision to develop land in rapid transit station areas (Figure 2). 
Table 1. Review of Factors Affecting Land Use Change with Rapid Transit

\begin{tabular}{|c|c|c|c|c|c|c|c|}
\hline Source & City (Line) & $\begin{array}{c}\text { 1. Transit } \\
\text { Accessibility }\end{array}$ & $\begin{array}{l}\text { 2. Positive Growth } \\
\text { \& Demand }\end{array}$ & $\begin{array}{l}\text { 3. Positive Social } \\
\text { Conditions }\end{array}$ & $\begin{array}{l}\text { 4. Positive Physical } \\
\text { Conditions }\end{array}$ & $\begin{array}{l}\text { 5. Available } \\
\text { Land }\end{array}$ & $\begin{array}{l}\text { 6. Complementary } \\
\text { Planning }\end{array}$ \\
\hline Cervero (1984) & $\begin{array}{l}\text { San Francisco (BART) } \\
\text { Washington, DC (Metrorail) } \\
\text { Calgary (C-Train) } \\
\text { San Diego (Trolley) }\end{array}$ & $\checkmark$ & $\checkmark$ & & $\checkmark$ & $\checkmark$ & $\checkmark$ \\
\hline Cervero and Landis (1997) & San Francisco (BART) & $\checkmark$ & $\checkmark$ & & $\checkmark$ & $\checkmark$ & $\checkmark$ \\
\hline Cervero \& Seskin (1995) & Literature review & $\checkmark$ & $\checkmark$ & $\checkmark$ & $\checkmark$ & $\checkmark$ & $\checkmark$ \\
\hline Giuliano (2004) & Literature review & $\checkmark$ & $\checkmark$ & & & & $\checkmark$ \\
\hline Gómez-lbáñez (1985) & $\begin{array}{l}\text { San Diego (Trolley) } \\
\text { Calgary (C-Train) } \\
\text { Edmonton (ETS LRT) }\end{array}$ & $\checkmark$ & $\checkmark$ & & & & $\checkmark$ \\
\hline Handy (2005) & Literature Review & $\checkmark$ & $\checkmark$ & & $\checkmark$ & $\checkmark$ & $\checkmark$ \\
\hline Huang (1996) & Literature review & $\checkmark$ & $\checkmark$ & & & $\checkmark$ & $\checkmark$ \\
\hline Knight and Trygg (1977a) & \multirow[b]{2}{*}{$\begin{array}{l}\text { San Francisco (BART) } \\
\text { Toronto (TTC) } \\
\text { Montreal (Metro) } \\
\text { Philadelphia (SEPTA) } \\
\text { Boston (MBTA Subway \& Streetcar) } \\
\text { Chicago (CTA Subway \& Streetcar) } \\
\text { Washington, DC (Metrorail) } \\
\text { Cleveland (RTS) } \\
\text { New York (PATH) } \\
\text { Los Angeles (El Monte Busway) } \\
\text { Seattle (Blue Streak Bus) } \\
\text { Miami (Blue Dash Bus) }\end{array}$} & $\checkmark$ & $\checkmark$ & $\checkmark$ & $\checkmark$ & $\checkmark$ & $\checkmark$ \\
\hline Knight and Trygg (1977b) & & $\checkmark$ & $\checkmark$ & & $\checkmark$ & $\checkmark$ & $\checkmark$ \\
\hline Vessali (1996) & Literature review & $\checkmark$ & $\checkmark$ & & & $\checkmark$ & $\checkmark$ \\
\hline
\end{tabular}




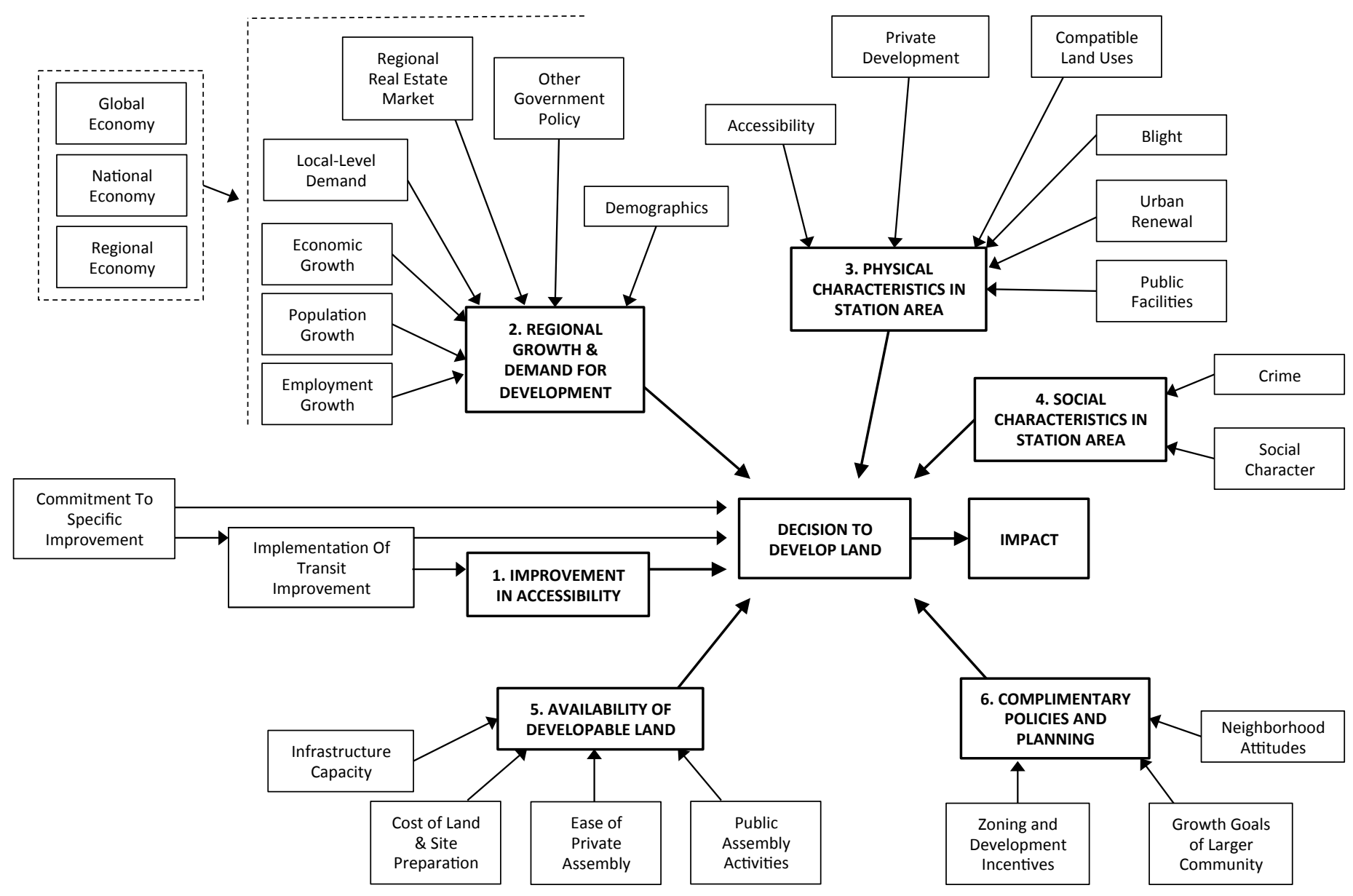

Source: Adapted from Knight and Trygg (1977a)

Figure 2. Factors influencing land use impacts 


\section{Improvement in accessibility}

Accessibility lies at the heart of locational advantages in an urban market where individuals base their locational decisions on a tradeoff between transportation costs and housing consumption, and the attractiveness of higher-density, mixed use TOD is dependent on rapid transit offering a competitive alternative to other modes for reaching destinations in the city. This includes accessibility at the start and end of a transit journey, emphasizing the importance of transit-based employment in addition to transit-based housing as well as connectivity to transit at the neighborhood level. While there may be some latent demand from individuals who would self-select to locate in a station area, if rapid transit offers only a marginal or negligible improvement in accessibility and reduction in transportation costs it is unlikely to create a transit-based locational advantage which can in turn negatively impact by choice ridership and land use change. This is especially relevant in cities that are uncongested or where a spatially-dispersed and automobile-oriented built environment is prevalent. In some cases, development or speculation can occur in advance of a transit facility beginning service based on perceived accessibility benefits.

\section{Positive regional economic, population, and employment growth and demand for development}

The land use impact of transit is conditional on the presence of regional economic, population, and employment growth that can be redistributed to a transit corridor and a healthy real estate market with demand for higher-density living. Languishing growth and a soft real estate market can mean higher risks for developers and lenders and may require significant market intervention to increase the supply of transit-oriented housing, although this does little to increase demand for such development. Demand also matters at the local level, as even if a region is experiencing rapid economic, population, and employment growth, there must be demand from developers to construct and individuals to live within the transit corridor. Other broad factors such as demographics, government policies such as taxation and interest rates, and the structure of the global, national, and regional economy and labor market also come together to shape the nature of supply and demand in the urban land market. This prerequisite also suggests an element of timing, as the potential redistributive impact of rapid transit is stronger if the facility enters service just prior to a period of rapid growth. 


\section{Positive physical conditions in transit corridor and station areas}

High quality physical environments that are friendly to pedestrians and feature amenities, public improvements, and streetscape enhancements are more hospitable to transit riders and thereby more attractive to developers, financers, and those presently or interested in living there. Conversely, a deteriorated housing stock or incompatible land uses can hurt demand for new development. This issue is related to the choice of transit corridor, as alignments in industrial areas or highway medians chosen for cost considerations can create a significant challenge to attracting transit-oriented land use change.

\section{Positive social conditions in transit corridor and station areas}

Social challenges, both real and perceived, can have long-lasting effects on the potential for land use change along a transit corridor, despite the best intentions of planners and policymakers. Positive social conditions play a vital role in the attractiveness of station areas for development for developers, financers, and prospective residents. Criminal activity can contribute to a perception of insecurity and other social issues such as poverty, unemployment, the quality of schools, or a general perception of disadvantage can all but erase market demand for certain locations.

\section{Available land for development and ease of land assembly}

Transit-oriented development is much more straightforward and profitable for developers if large parcels of land are already available, cheap, and suitable for development. Land assembly can be a costly and time-consuming process and can benefit from the help of the public sector. In some respects, development within established city cores may be at a natural disadvantage compared to greenfield locations, although development incentives may offset this.

\section{Complementary government planning and policy}

Policies designed to incentivize TOD and level the playing field for the transit mode are a critical factor in strengthening the relationship between rapid transit and land use change. This includes a package of zoning, financing, and planning policies to promote transit-oriented development, parking and road investment policies that restrict travel by automobile, and complementary regional policies such as urban growth boundaries and densification targets and the correction of market distortions such as the underpricing of automobile travel.

Complementary land use planning and policies have gained considerable attention in recent years. Planners of first-generation light rail and other rail transit projects 
tended to view transit stations as natural "magnets" for development and saw land use planning as separate from transportation, preferring to leave development to the market. But the general underperformance of these systems in terms of land use change has resulted in increasing attention paid to TOD by academics, planners, and policymakers. A pivotal turning point came in 1998 when six explicit land use criteria became part of the Federal Transit Administration's (FTA) process for evaluating New Starts projects (Deakin et al. 2002). In response, concurrent and advance land use planning is now an integral part of the transit planning process within the vast majority of rail transit agencies in the United States (Cervero et al. 2004).

\section{Factor Impact and Interactions}

While the six primary factors listed above appear to be relatively straightforward, such an approach offers no information on the relative weight of each or interactions between them, leaving researchers with many unanswered questions regarding their effect in practice. For example, which factors are most important in tipping the balance towards development? Is there a point at which some factors can overcome others, such as using a suite of developmental incentives to overcome a less-than-ideal social or physical environment?

Definitive answers to these questions remain elusive, although the literature does offer some insight. A first consideration is the ability of rail transit to increase accessibility and create locational advantages. Previous authors consistently mentioned accessibility as an important condition for inducing land use change in transit station areas and rail has been shown to be a major driver of development in the 'streetcar suburbs' of the past (Bernick and Cervero 1997). But road systems in North American cities have become highly developed since that time, and the transit system is only a small portion of the entire transportation network (Giuliano 2004). Subsequently, the ability of light rail and other rapid transit to create an accessibility-based locational advantage within this context, particularly in highly automobile-oriented cities, is severely weakened, thus limiting one of rapid transit's strongest natural impacts on shaping land use within the urban system.

Nevertheless, rail is competitive in certain urban contexts, as the examples below will show. Reductions in automobility that result from congestion or targeted public policies can also benefit transit accessibility. Furthermore, the other five factors can augment accessibility to strengthen the ability of rail transit to induce land use change. 
Given rail's potentially marginal effect on accessibility, the biggest emphasis in the literature for promoting land use change is on complimentary land use policies and planning. Meyer and Gómez-lbáñez (1981) contend that a comprehensive package of land use planning policies and incentives can affect urban form far more than transit planning. But transit remains important as the process of transit planning is itself often a major catalyst for more intensive land use planning that might not otherwise have occurred (Vesalli 1996).

Regional growth and demand for development is also fundamental. As summarized by Vessali (1996): "Almost exclusively, transit systems' impacts on land use are limited to rapidly growing regions with a healthy underlying demand for development" (p. 97). In short, there must be growth to redistribute to a transit corridor if measureable land use change is to occur. Recent research by Hess and Almeida (2007) supports this position. Though transit-oriented land use change is considered most likely in central cities, the authors find a distinct lack of new projects in the downtown areas of slow growth and economically distressed cities. Meyer and Gómez-lbáñez (1981) argue that positive growth is more important than complementary land use policies and planning as "if there is no underlying demand for high-density development, then almost no combination of public policies will elicit a compact urban structure" (p. 127).

The remaining factors of social and physical conditions and available land for development in station areas are cited with less frequency, suggesting they play a smaller role in the development decision. However, access issues, incompatible surrounding land uses, transit stations in highway medians, crime, and other related challenges have been shown to preclude development. Moreover, as recent experiences with light rail below demonstrate, all six of these factors continue to shape the land use impacts of LRT and other rapid transit.

\section{Recent Experiences with Light Rail and Land Use in Practice}

Previous research on experiences with light rail in several cities offers some more recent insight into the role of these factors in inducing land use change in station areas, though no one study has examined the impact of all six factors concurrently. While they can be low in some contexts and are generally accepted as less than that of heavy rail, accessibility benefits are cited as the root cause of significant new development along Jersey City's Hudson-Bergen LRT. The line, which opened in 2000, links several major residential and employment destinations and features 
a direct connection to the PATH rapid transit system in New Jersey and New York City (Cervero et al. 2004; Robins and Wells 2008).

Cervero et al.'s (2004) review of experiences with TOD offer a number of insights into recent experiences with light rail and land use change in the United States. The authors cite strong market demand as a factor contributing to development around DART LRT stations in the Dallas metropolitan area, although they note that the functional connections to transit in the bulk of these projects is lacking. Outside of the city of Dallas, smaller cities such as Plano have used supportive planning policies to generate new transit-oriented development.

Two of the most widely-cited examples of complementary land use planning and policy are San Diego and Portland, the latter of which is considered by Cervero et al. (2004) to have among the most aggressive TOD programs in the nation. Although San Diego's southern leg of the Trolley to the Mexican border boasts impressive ridership, land use change along the line has been non-existent, largely due to its alignment along freight rail tracks in an industrial corridor. Future lines and extensions have been chosen based on developmental potential and, in concert with a strong real estate market, traffic congestion, demographics, population, and employment growth, as well as a progressive package of supporting public policies, new development in station areas has been commonplace

At the time of writing, Cervero et al. (2004) found that nearly every one of Portland's LRT stations saw some form of new development, thus increasing the multiplier effect of homes, jobs, and activity centers along its transit lines. Nevertheless, planners there are quick to point out that the City's policy and planning incentives did not create demand for TOD and instead credit demographics and individual preferences for driving the market for development in LRT station areas. But Portland's new Green Line LRT runs along Interstate 205, and experiences in other cities suggest that such an alignment can negatively impact prospects for new transit-oriented development. In this sense, it will be interesting to see if market demand and supportive public policies can overcome such a physical environment to promote land use change as the line matures.

Social challenges are less cited in the literature, although they have been found to have an effect on development. According to Loukaitou-Sideris and Banerjee (2000), poverty, unemployment, crime, and gang violence combined with physical issues such as inaccessible stations, poor pedestrian connections, incompatible surrounding land uses, and a deteriorated housing stock along the Blue Line LRT in Los Angeles have resulted in an environment described as "derelict and forbidding"( $p$. 
10). This negative image was said to be a major factor precluding investment and development in many station areas.

Among new LRT systems, notable recent examples of land use change and revitalization attributed to complementary planning and policy include new lines and system extensions in Minneapolis, Denver, and Charlotte, which opened in 2004, 2006, and 2007, respectively (Fogarty and Austin 2011). Of these, both Minneapolis and Charlotte experienced considerable new investment around light rail stations in their central areas, and Fogarty and Austin (2011) attribute much of this to public policies in support of TOD as well as local factors such as accessibility and proximity to major employment areas, positive regional growth, a strong real estate market and demand for development, available land, and good physical connections to transit at the neighborhood level. However, these factors were not present at all stations along each line and, subsequently, development remains uneven, particularly outside of the central city. In Denver, there has been some development along the Southeast Corridor LRT, although it is not clearly due to transit and the developmental potential of the line is hurt by its location in a highway median (Fogarty \& Austin 2011).

The land use impact of other recent LRT systems is less clear. Considerable land use planning was completed in advance of light rail in Phoenix, which began service in 2008 (Atkinson-Palombo and Kuby 2011). Kittrell (2012) has shown that these efforts have worked to some degree with a refocusing of development in downtown Phoenix, although in other cases new zoning incentives for TOD appear to have been ignored in favor of automobile-oriented projects. Valley Metro (2013) has released periodic economic development updates with the most recent detailing nearly $\$ 7$ billion in new development near LRT stations since 2004. Land use change in Phoenix has likely been hindered to some degree by real estate speculation that occurred between 1998 and 2000 after station locations were announced (Kittrell 2012), a problem has previously been said to negatively affect land use development related to rapid transit elsewhere (Cervero 1985; Vesalli 1996). Other large-scale factors, such as the global economic crisis and recession of 2007-2008, have no doubt had an impact as well. However, no other empirical studies of the land use impact of LRT in Phoenix exist.

Property values have increased in Houston LRT station areas since METRORail began service in 2004 (Pan 2013). But like Phoenix, empirical research on new development associated with LRT remains sparse. Pan (2013) anecdotally notes one new condominium project within walking distance of a station. Research con- 
ducted by the authors indicates some changes have occurred, with a small number of new condominium projects as well as significant new developments around the Texas Medical Center. However, many station areas throughout the system remain dominated by surface parking. METRORail's construction without federal funding means it was not subject to creating a land use planning program in line with FTA's evaluation criteria and the city's lack of traditional zoning regulations make it a relatively unique case in North America. This may change in the future, as Houston launched its Urban Corridor Planning initiative in 2009 and new system extensions approved in 2011 will receive almost $\$ 800$ million in federal funds, although FTA (2009) rates the city's land use initiatives as medium to low.

After what Brown and Thompson (2009) characterized as a distinct lack of new TOD in TRAX station areas along its first phases of LRT, Salt Lake City is now aggressively pursuing several ambitious TOD projects on agency-owned land through FTA's joint development program at stations along new Green and Red Line extensions that opened in 2011 (Olson 2011). Several other cities have completed new light rail lines and system extensions since 2005, such as Los Angeles, Norfolk, Dallas, Portland, San Diego, and Sacramento. However, the relative immaturity of these systems means it will be some time before researchers are able to decipher their long-term ability to shape urban growth and development. Nevertheless, the information on the recent cases explored thus far suggests that the six factors that affect land use remain as relevant today as they did when they were first published several decades prior.

\section{Causality, Confounding Influences, and the Effectiveness of Development}

We began this paper questioning the role of light rail and other rail transit in promoting land use change and revitalization. But the evidence presented thus far paints only a partial picture of that process. Six important factors have been identified that influence land use development around rapid transit stations and some appear to carry more weight, though this conclusion is based simply on the frequency of their citations in the previous literature.

However, a more quantified analysis of the impacts of and interactions between the six factors identified above is beset by a number of challenges. A significant obstacle is the battery of confounding influences that inform each and local contextual factors in station areas. According to Giuliano (2004), the largest issues that plague attempts to clarify the relationship between rapid transit and land use 
development are first the highly-dynamic nature of the urban system where many changes are occurring at any given moment in addition to the transit investment, and second, the long time horizon involved in market responses to these changes, which can span decades. A consequence of these issues is that it is especially difficult to determine the nuanced forces at work and the direction of causality in land use changes that have occurred as a result of land use planning in tandem with a transit investment, leading Giuliano (2004) to remark that "land use and transportation decisions are so closely tied together that it has been impossible so far to separate their effects" (p. 254). Subsequently, no authors have attempted to comprehensively disentangle the factors that have influenced development in station areas with previous work limited to "draw(ing) inferences by looking at a handful of time slices using less-than-complete data" (Cervero and Landis, 1997, p. 311).

Nevertheless, quantitative research using advanced statistical methods can isolate the six factors above while controlling for any additional influences that may be relevant to a particular case. This type of analysis is, of course, predicated on the availability of a longitudinal data set of sufficient scope and quality, one that has to date remained elusive. Still, such an approach is necessary for increasing our knowledge of which factors matter most and why.

\section{Conclusions}

If a rail transit system is to have high levels of initial ridership, it is essential that it be located along a corridor with high levels of existing demand. However, it is often the potential for promoting transit-oriented land use change that emerges as a central planning consideration for achieving long-term ridership goals. Many cities have witnessed new TOD associated with light rail and other rail transit over the past two decades, and there is no question that a narrative in pursuit of this objective is a fundamental factor in shaping public and political support for such a project. But it has been more than 35 years since Knight and Trygg (1977b) cautioned that "unreasonable claims of transit's power to induce major land use change must be avoided" (p. 245). Although these systems can bring considerable benefits to host cities, years of research demonstrate that local conditions must be receptive if these systems are to have a measurable impact on land use change. In response, rail transit is best understood not as a driver of new growth and land use change on its own, but as a singular element in a long-term effort to shape growth and revitalization in host cities. 
In this paper we have delineated six important factors that influence land use change associated with light rail and other rapid transit, although no study to date has explicitly attempted to disentangle the role of each in the development decision and their piecemeal application in studies that have occurred leaves researchers with a fragmented set of conclusions. Factors such as an increase in accessibility, regional growth and demand for development, and supportive public policies are cited most frequently and appear to carry the most weight, although social and physical conditions and available land are also important.

Confounding influences, long time horizons, and the complexities of individual station area contexts will make greater quantitative determinations of association and causality among these factors challenging. Nevertheless, future quantitative research on the positive and negative influences associated with development in station areas should be conducted taking all six of these factors into account, thereby standardizing research in this area and providing more evidence as to their importance in the development decision This is particularly important for testing the impact and effectiveness of newer "second generation" light rail lines and extensions that are an outcome of the FTA's greater emphasis on concurrent land use planning. Only then can we surpass the limits of previous research to obtain a more complete picture of the role of light rail and other rapid transit in reshaping and revitalizing cities.

\section{References}

Atkinson-Palombo, C., and M. J. Kuby. 2011. The geography of advance transitoriented development in metropolitan Phoenix, Arizona, 2000-2007. Journal of Transport Geography 19: 189-199.

Babalik-Sutcliffe, E. 2002. Urban rail systems: Analysis of the factors behind success. Transport Reviews 22(4): 415-447.

Bernick, M., and R. Cervero. 1997. Transit Villages in the 21st Century. New York, NY: McGraw-Hill.

Black, A. 1993. The recent popularity of light rail transit in North America. Journal of Planning Education and Research 12(2): 150-159.

Brown, J. R., and G. L. Thompson. 2009. The influence of service planning decision on rail transit success or failure. Mineta Transportation Institute, San Jose State University. 
Cervero, R. 1985. A tale of two cities: Light rail transit in Canada. Journal of Transportation Engineering 111: 633-650.

Cervero, R. 1984. Light rail transit and urban development. Journal of the American Planning Association 50: 133-147.

Cervero, R., and J. Landis. 1997. Twenty years of the Bay Area Rapid Transit System: Land use and development impacts. Transportation Research Part A 31(4): 309-333.

Cervero, R., and S. Seskin. 1995. An evaluation of the relationships between transit and urban form. Research Results Digest. Washington, DC: Transportation Research Board.

Cervero, R., S. Murphy, C. Ferrell, N. Goguts, Y. H. Tsai, G. B. Arrington, et al. 2004. Transit-oriented development in the united states: Experiences, challenges, and prospects. Transit Cooperative Research Program. Washington, DC: Transportation Research Board.

City of Hamilton. 2010. Moving Hamilton forward with LRT. Public Works Department. Hamilton, ON: City of Hamilton.

Cohen-Blankshtain, G., and E. Feitelson. 2011. Light rail routing: Do goals matter? Transportation 38: 343-361.

Currie, G., A. Ahern, and A. Delbosc. 2011. Exploring the drivers of light rail ridership: An empirical route level analysis of selected Australian, North American and European systems. Transportation 38: 545-560.

Deakin, E., C. Ferrell, J. Mason, and J. Thomas. 2002. Policies and practices for costeffective transit investment: Recent experiences in the United States. Transportation Research Record 1799: 1-9.

Ewing, R., and R. Cervero. 2010. Travel and the built environment: A meta-analysis. Journal of the American Planning Association 76(3): 265-294.

Flyvbjerg, B., M. Holm, and S. L. Buhl. 2005. How (in)accurate are demand forecasts in public works projects? The case of transportation. Journal of the American Planning Association 71(2): 131-146.

Fogarty, N., and M. Austin. 2011. Rails to Real Estate: Development Patterns along Three New Transit Lines. Washington, DC: Center for Transit-Oriented Development. 
FTA. 2009. University corridor LRT: Houston, Texas: Preliminary engineering. Washington, DC: Federal Transit Administration.

Giuliano, G. 2004. Land use impacts of transportation investments: Gighway and transit. In S. Hanson and G. Giuliano (Eds.), The Geography of Urban Transportation, 3rd Edition. New York: Guilford Press.

Gómez-lbáñez, J. A. 1985. A dark side to light rail? The experience of three new transit systems. Journal of the American Planning Association 51(3): 337-351.

Handy, S. 2005. Smart growth and the transportation-land use connection: What does the research tell us? International Regional Science Review 28(2): 146-167.

Hass-Klau, C., and G. Crampton. 2002. Future of Urban Transport: Learning from Success and Weakness: Light Rail. Brighton, UK: Environment and Transport Planning.

Hess, D. B., and T. M. Almeida. 2007. Impact of proximity to light rail rapid transit on station-area property values in Buffalo, New York. Urban Studies 44(5/6): 1041-1068.

Huang, H. 1996. The land-use impacts of urban rail transit systems. Journal of Planning Literature 11(1): 17-30.

Kittrell, K. 2012. Impacts of vacant land values: Comparison of metro light rail station areas in Phoenix, Arizona. Transportation Research Record 2276: 138-145.

Knight, R. L., and L. L. Trygg. 1977a. Land Use Impacts of Rapid Transit: Implications of Recent Experience. Office of the Secretary. Washington, DC: U.S. Department of Transportation.

Knight, R. L., and L. L. Trygg. 1977b. Urban mass transit and land use impacts. Transportation 5(1): 12-24.

Kuby, M., A. Barranda, and C. Upchurch. 2004. Factors influencing light rail station boardings in the United States. Transportation Research Part A 38(3): 223-247.

Loukaitou-Sideris, A., and T. Banerjee. 2000. The blue line blues: Why the vision of transit village may not materialize despite impressive growth in transit ridership. Journal of Urban Design 5(2): 101-125.

Mackett, R. L., and M. Edwards. 1998. The impact of new urban public transport systems: Will the expectations be met? Transportation Research Part A 32(4): 231-245. 
Meyer, J. R., and J. A. Gómez-lbáñez. 1981. Autos, Transit, and Cities. Cambridge, MA: Harvard University Press.

Olson, K. 2011. Bending the market - using joint development as a catalyst. Salt Lake City, UT: Utah Transit Authority.

Pan, Q. 2013. The impacts of an urban light rail system on residential property values: A case study of the Houston METRORail Transit Line. Transportation Planning and Technology 36(2): 145-169.

Pickrell, D. H. 1992. A desire named streetcar: Fantasy and fact in rail transit planning. Journal of the American Planning Association 58(2): 158-176.

Pushkarev, B. S., and J. M. Zupan. 1977. Public Transportation and Land Use Policy. Bloomington, IN: Indiana University Press.

Robins, M. E., and J. S. Wells. 2008. Land development at selected Hudson-Bergen light rail stations. New Brunswick, NJ: Alan M Voorhees Transportation Center.

Siemiatycki, M. 2009. Academics and auditors: Comparing perspectives on transportation project cost overruns. Journal of Planning Education and Research 29: $142-156$.

Valley Metro. 2013. Light rail economic development highlights. Phoenix, AZ: Valley Metro.

Vesalli, K. V. 1996. Land use impacts of rapid transit: A review of the empirical literature. Berkeley Planning Journal 11: 71-105.

Wachs, M. 1987. Forecasts in urban transportation planning: Uses, methods, and dilemmas. Climate Change 11: 61-80.

\section{About the Authors}

Christopher Higgins (higgicd@mcmaster.ca) is a Ph.D. Candidate at the School of Geography and Earth Sciences at McMaster University in Hamilton, Ontario, Canada, and a Research Assistant at the McMaster Institute for Transportation and Logistics. His research interests include urban transit planning, transit finance through land value capture, public-private partnerships, and the spatial analysis of centralization in cities. 
MARK Ferguson (fergumr@mcmaster.ca) is Research Coordinator and a Senior Researcher with the McMaster Institute for Transportation and Logistics. He holds a Ph.D. in Geography from McMaster University and has published more than a dozen articles in international journals. His academic experience is complemented by more than a decade of private sector experience working on consulting projects primarily for banking and retail clients.

Pavlos Kanaroglou (pavlos@mcmaster.ca) is Canada Research Chair in Spatial Analysis, Director of McMaster's Institute for Transportation and Logistics, and Professor in the School of Geography and Earth Sciences at McMaster University. His interests include the development of methods in spatial analysis and the application of such methods to urban transportation and the relationship between environmental pollution and health. 